\title{
Türkiye Kara Alanlarında Delinen Petrol ve Doğalgaz Kuyularında Kullanılan Sondaj Akışkanı Katkı Maddeleri
}

\author{
Ahmet Güllü ${ }^{*}$, Adil Özdemir², Yıldıray Palabıyık ${ }^{3}$, Ergül Yaşar ${ }^{4}$

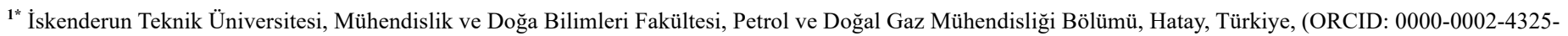 \\ 388X), ahmetgullu725@gmail.com \\ ${ }^{2}$ Atatürk Üniversitesi, Fen Bilimleri Enstitüsü, Jeoloji Mühendisliği Anabilim Dalı, Erzurum, Türkiye, (ORCID: 0000-0002-3975-2846), adilozdemir2000@yahoo.com \\ ${ }^{3}$ İstanbul Teknik Üniversitesi, Maden Fakültesi, Petrol ve Doğal Gaz Mühendisliği Bölümü, İstanbul, Türkiye, (ORCID: 0000-0002-6452-2858), palabiyiky@,itu.edu.tr \\ ${ }^{4}$ İskenderun Teknik Üniversitesi, Mühendislik ve Doğa Bilimleri Fakültesi, Petrol ve Doğal Gaz Mühendisliği Bölümü, Hatay, Türkiye, (ORCID: 0000-0002-1290- \\ 749X), ergul.yasar@iste.edu.tr
}

(İlk Geliş Tarihi 19 Haziran 2021 ve Kabul Tarihi 9 Eylül 2021)

(DOI: 10.31590/ejosat.954723)

ATIF/REFERENCE: Güllü, A., Özdemir, A., Palabıyık, Y. \& Yaşar, E. (2021). Türkiye Kara Alanlarındaki Petrol ve Doğalgaz Kuyularında Kullanılan Sondaj Akışkanı Katkı Maddeleri. Avrupa Bilim ve Teknoloji Dergisi, (27), 398-406.

\section{$\ddot{O} \mathbf{z}$}

Petrol ve doğalgaz sondajlarında kullanılan ileri teknolojinin zor ve yüksek maliyetli olmasından dolayı sondajların hedeflenen derinlik ve amaç doğrultusunda en uygun koşullarda, en kısa sürede ve en düşük maliyet ile tamamlanması gerekir. Sondaj çalışmalarında istenilen derinlik ve amaca ulaşllabilmesi için en önemli unsurlardan birisi, sondaj çamuru kontrolüdür. Bu çalışmada, Türkiye kara alanlarında 1963 - 2021 yılları arasında kazılmış olan 470 adet petrol ve doğalgaz kuyusuna ait kuyu bitirme raporları incelenmiştir. Bu kuyularda kullanılan çamur katkı maddesi tipleri ve miktarları değerlendirilmiştir. Böylelikle, bu çalışmanın sondaj çamuru verilerinin değerlendirmeye alınarak gelecek sondaj kuyularının düşük maliyetli ve güvenli bir şekilde kazılmasına katkı sağlanması amaçlanmaktadır.

Anahtar Kelimeler: Sondaj akışkanı, Sondaj çamuru, Sondaj akışkanı katkı maddeleri, Petrol sondajı, Doğalgaz sondajı.

\section{Drilling Fluid Additives Used in Oil and Gas Wells Drilled in Onshore of Turkey}

\begin{abstract}
Oil and gas extraction is a difficult and high-tech process. Oil and gas drilling wells are costly. Since the advanced technology used in oilwell drilling is difficult and costly, the drilling must be completed in the most appropriate conditions, in the shortest time, with costeffective and the targeted depths and purposes. Control of drilling mud is one of the most important factors in achieving these desired goals in drilling operations. In this study, the reports of 470 oil and gas wells drilled in 1963 - 2021 in onshore Turkey were analyzed. Types and amounts of mud additives used in these wells were evaluated. Thus, it is aimed to contribute to the cost-effective and safe drilling of future wells by evaluating the drilling mud data of this study.
\end{abstract}

Keywords: Drilling fluid, Drilling mud, Drilling fluid additives, Oilwell drilling, Gaswell drilling.

\footnotetext{
*Sorumlu Yazar: ahmetgullu725@gmail.com
} 


\section{Giriş}

Sondaj çamur türleri, derinlik ve formasyona göre değişiklik göstermektedir. Genellikle başlangıçta spud tip, devamında lignosülfonat tip ve rezervuar derinliğe ulaşıldığında polimer tip sondaj çamuru kullanılmaktadır. Bu çalışmada, Türkiye kara alanlarında kazılmış olan ve verisi değerlendirilen 470 adet petrol ve doğalgaz sondaj kuyusunda, sı ̆ derinliklerde $(0-50$ m) spud çamuru, daha sonraki derinliklerde de lignosülfanat çamuru kullanıldığı görülmüştür (Güllü ve diğ., 2021; Ettehadi, 2021; Acar ve di ̌̆., 2020).

Spud çamuru, genel olarak sondaj operasyonunun ilk metrajlarında, kuyu çapının en büyük olduğu aralığın delinmesi sırasında kullanılan çamur türüdür. Su bazlı çamur türlerinden olup, reaktif çamurlardan biridir. Spud çamurlarının temel katkı maddesi bentonittir. Su sertliğini azaltmak amacı ile soda külü, pH kontrolü için ise kostik soda kullanılmaktadır. Spud çamuru hazırlanması kolay olduğu için sıklıkla tercih edilir. Uygun reolojik özellikler ve iyi hidrolik planlama ile geniş kuyu anülüsünde biriken büyük boyutlu kesintilerin temizlenerek yüzeye getirilmesini sağlar.

Lignosülfonat çamuru, sondaj derinliğinin artması ile birlikte kullanılmaya başlanılan tatlı su kaynaklı bir reaktif çamur türüdür. Bu tip çamurlarda, bentonit, kostik soda, soda külü, CMC-HV (karboksimetil selüloz, yüksek viskozite), CMCLV (karboksimetil selüloz, düşük viskozite), PAC-LV (polianyonik selüloz, düşük viskozite), XCD polimer, barit ve $\mathrm{CaCO}_{3}$, sitrik asit vb. gibi kimyasallar kullanılmaktadır. Lignosülfanat çamuru, hazırlanması ve bakımı kolay ve ucuz bir çamur tipidir. Yaygın olarak kullanılan bu çamur türü, çok özel sondaj problemleri yaşanmadığı sürece başarıyla kullanılmaktadır.

Petrol ve doğalgaz sondajlarında kullanılan ileri teknolojinin zor ve yüksek maliyetli olmasından dolayı sondajların hedeflenen derinlikler ve amaçlar doğrultusunda en uygun koşullarda, en kısa sürede ve en az maliyet ile tamamlanması gerekir (Özdemir ve diğ., 2021a-c). Sondaj çalışmalarında istenilen bu amaçlara ulaşılabilmesi için en önemli unsurlardan birisi sondaj çamurunun kontrolüdür (Büyükgöz, 2004; Balkaya, 2019; Tuğan ve diğ., 2020). Bu amaçla, Türkiye kara alanlarında 1963 - 2021 yılları arasında kazılmış olan kuyularda kullanılan çamur katkı maddeleri tipleri ve miktarları değerlendirilmiştir.

\section{Materyal ve Metot}

$\mathrm{Bu}$ çalışmada, Türkiye kara alanı havzalarında kazılmış olan 470 adet petrol ve doğalgaz sondaj kuyusuna ait ham veriler işlenmiş ve yorumlanmıştır. Çalışma kapsamında, sondaj çamuru katk1 maddeleri verisi değerlendirilen ve yorumlanan kuyulara ait bilgiler şu şekildedir;

- Kuyu lokasyonları: Verisi değerlendirilen kuyuların çoğunluğu (\% 79’u), Türkiye'nin petrol ve doğalgaz üretiminin tamamına yakınının yapıldığı Güneydoğu Anadolu ve Trakya havzalarında açılmıștır. Kuyuların büyük kısmı; Adıyaman, Batman, Diyarbakır, Kırklareli ve Tekirdağ illerindedir (Şekil 1).

- Kuyuların kazıldığı yıllar: Verisi değerlendirilen 470 adet petrol ve doğalgaz kuyusu 1963 - 2021 yılları arasında kazılmıştır. Kuyuların maliyet ve süre değerlendirmelerinin temsil edici olması için kuyuların yıllara göre dağılımının olabildiğince homojen olasına özen gösterilmiştir (Şekil 2).

- Kuyu tipleri: İncelenen kuyular; olabildiğince homojen olacak şekilde arama, tespit ve üretim kuyularından seçilmiştir. Veriye, sinırlı da olsa depolama ve enjeksiyon kuyuları da eklenmiştir (Şekil 3).

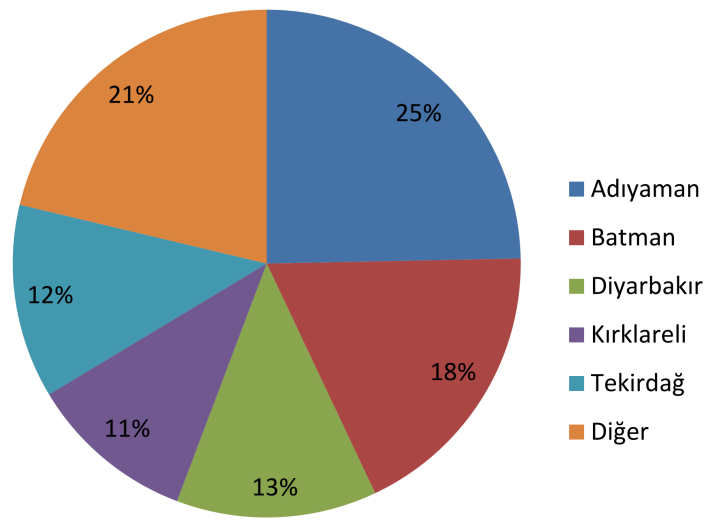

Şekil 1. Verisi değerlendirilen petrol ve doğalgaz kuyularının illere göre dağıllm yüzdesi

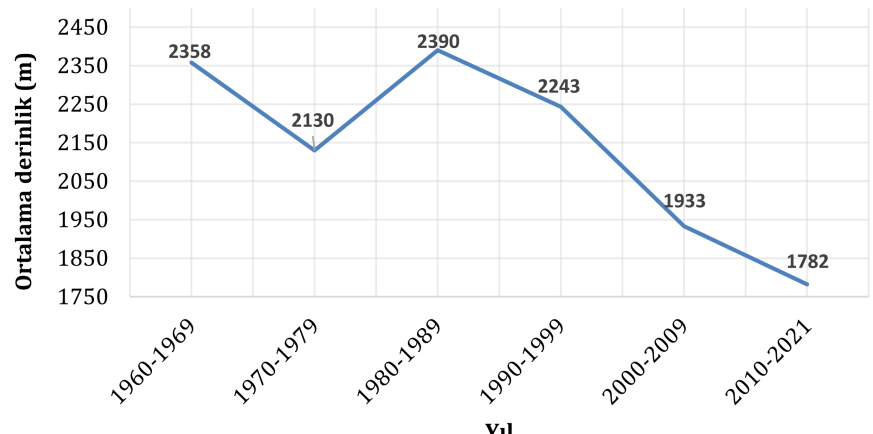

Şekil 2. Verisi kullanılan petrol ve doğalgaz sondaj kuyularının ylllara göre ortalama derinlikleri

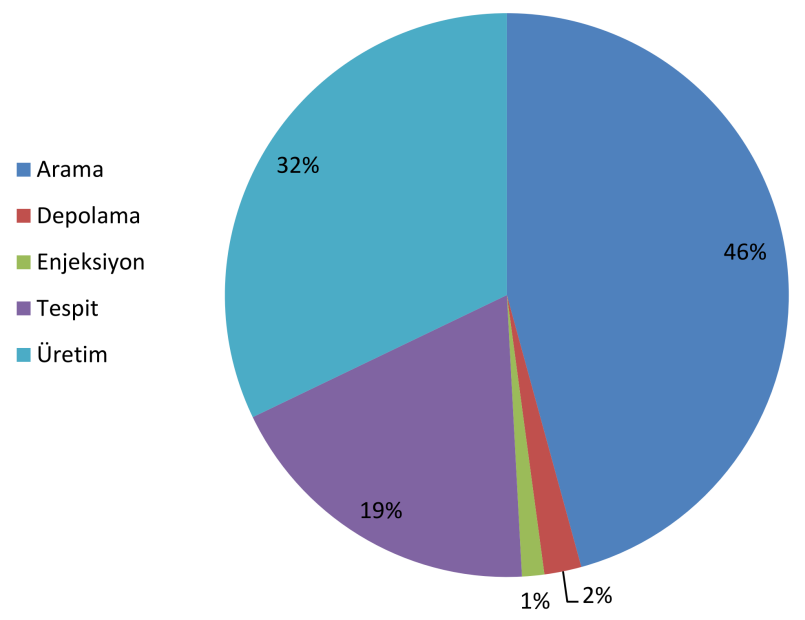

Şekil 3. Verisi kullanilan petrol ve doğalgaz sondaj kuyularının tiplerine göre dağıllım

- Kuyu derinlikleri: Sondaj sırasında ulaşılan derinliği belirtir. Verisi değerlendirilen kuyu derinlikleri, 500 - 5000 metre arasindadır. Kuyuların \% 86 's1 1000 - 3000 m derinliktedir. Ortalama kuyu derinliği, $1959 \mathrm{~m}$ olarak hesaplanmıştır (Şekil 4). 


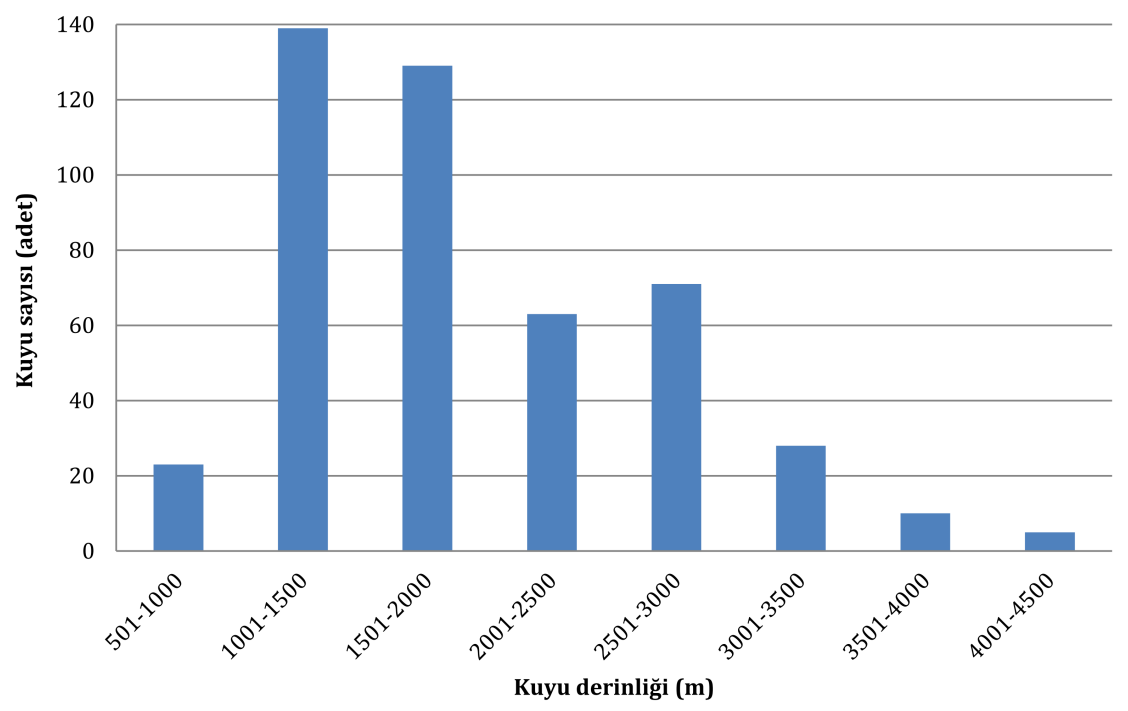

Şekil 4. Verisi kullanılan petrol ve doğalgaz sondaj kuyularının derinliklerine göre dă̆ıllımı

\section{Bulgular ve Tartış̧ma}

Çamurun sondaj işlemlerindeki görevleri şu şekilde özetlenebilir: almak,

1. Kuyu duvarını sıvamak suretiyle kuyuyu koruma altına

2. Matkabi soğutmak,

3. Matkabın kestiği kırıntıları kuyu dışına atmak suretiyle kuyu ve matkabi temizlemek,

4. Kuyu duvarında oyuklar oluşmasını önlemek,

5. Formasyonu yumuşatmak,

6. Formasyon basıncını önlemek,

7. Kullanılan ekipmanları yağlamak,

8. Sondaj ekipmanlarındaki aşınma ve paslanmayı azaltmak,

9. Takım ve muhafaza borularının hareketini kolaylaştırmak,

10. Yüzeye çıkardığı kırıntıların çamur havuzunda çökelmesini ve çökelen bu kırıntılardan jeolojik bilgi edinilmesini sağlamak,

11. Sondaj sırasında, formasyona su sızmasını önlemek,

12. Muhafaza borusu kullanımını azaltmak,

13. Takım ağırlığını azaltmaktır.

Sondaj çamurunun bu amaçları gerçekleştirebilmesi için sıvı bazlı akışkana birçok doğal ve yapay katkı maddesi eklenmektedir. Bu çalışmada, Türkiye kara alanlarında 1963 2021 yılları arasında kazılmış olan 470 adet petrol ve doğalgaz kuyusunda, kullanılan çamur katkı maddeleri tipleri ve miktarları değerlendirilmiş̧tir.

\subsection{Bentonit}

Bentonit, tatlı su esaslı çamurlardan tuzlu su çamurlarına kadar hemen hemen bütün çamur kompozisyonlarında yer alan, yüksek sicaklık ve değişik kimyasal ortamlarda kullanılan temel bir katkı maddesidir. Bentonit, çamurun önemli akış özelliklerini sağladığı gibi özel tane şekli ve boyutu nedeniyle çok iyi bir sıvı kaybı kontrolü de yapar. Bentonit torbaları, piyasadan genel olarak 50'şer kg'lık ambalajlar şeklinde temin edilmektedir. Çalışma kapsamında incelenen 470 adet petrol ve doğalgaz sondajında kullanılan bentonit miktarları Şekil 5'de verilmiştir. Şekilde görüleceği üzere, kuyu derinlikleri arttıkça kullanılan bentonit miktarının arttığı görülmektedir. Bunun sebebi, kuyu derinlikleri arttıça kuyu içi hidrostatik basınçların dengelenmesi için sondaj çamuru yoğunluğunun dengede tutulma zorunluluğunun ortaya çıkmasıdır.

e-ISSN : 2148-2683

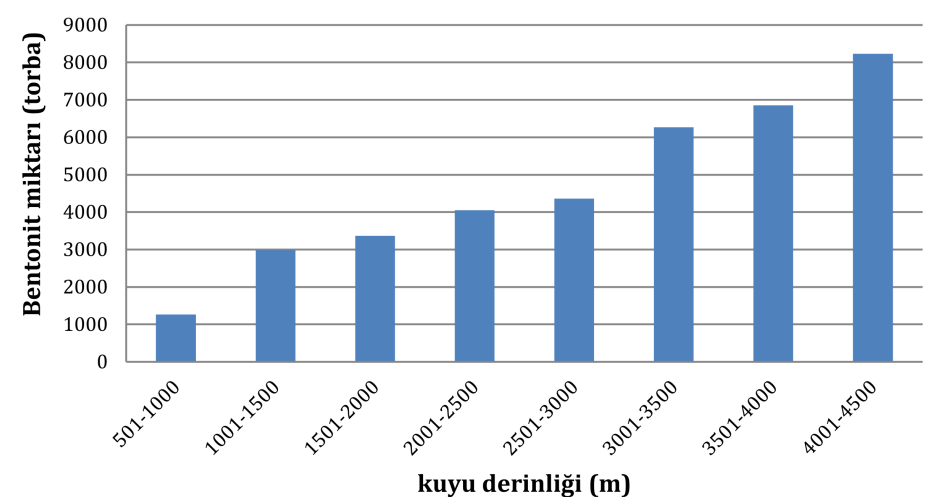

Şekil 5. Kuyularda kullanılan bentonit miktarı

\subsection{Ağırlaştırıcı Katkı Maddeleri}

Çamur ağırlığını istenilen seviyeye getirmek için kullanılan maddelerdir. Barit, hematit, kalsiyum karbonat gibi maddeler bunlara örnek gösterilebilir. Farklı özgül ağırlıklara sahip bu katı maddelerin belirli konsantrasyonlarda kullanılması ile istenilen çamur ağırlığı sağlanabilir.

Barit $\left(\mathrm{BaSO}_{3}\right)$ : Sondaj çamurlarının ağırlığını arttırmak için kullanılan barit, ağırlaştırıcı olarak bütün çamur tiplerinde kullanılabilir. Çalışma kapsamında incelenen 470 adet petrol ve doğalgaz sondajında kullanılan barit miktarları SSekil 6'da verilmiştir. Şekilde, kuyularda 3000 - 3500 m derinliklere kadar kullanılan barit miktarının kuyu derinliği artışına paralel olarak arttığı görülmektedir. Bu derinliklerden sonra ise kısmi bir dengelenme söz konusudur Burada çıkarılacak sonuç, kuyu derinlikleri arttıkça kuyu içi hidrostatik basınçların dengelenmesi için sondaj çamuru yoğunluğunun arttırılma zorunluluğunun ortaya çıkmasıdır.

Kalsiyum Karbonat $\left(\mathrm{CaCO}_{3}\right)$ : Formasyon kirlenmesini önlemek amacıyla üretim zonlarının delinmesi için planlanan sondaj sıvılarının ağırlığını arttırmak için kullanılan kalsiyum karbonat, $\mathrm{HCl}$ asitte tamamen çözünmektedir. $\mathrm{Bu}$ özelliğinden ötürü üretim zonları geçilirken gerek ağırlaştırıcı gerekse kaçak önleyici olarak bütün çamur tiplerinde kullanılabilir. Çalışma kapsamında incelenen 470 adet petrol ve doğalgaz sondajında kullanılan $\mathrm{CaCO}_{3}$ miktarları Şekil 7'de verilmiştir. $\mathrm{CaCO}_{3}$ kullanım miktarlarının, kuyu derinliklerine göre oldukça değişken olduğu görülmektedir. 


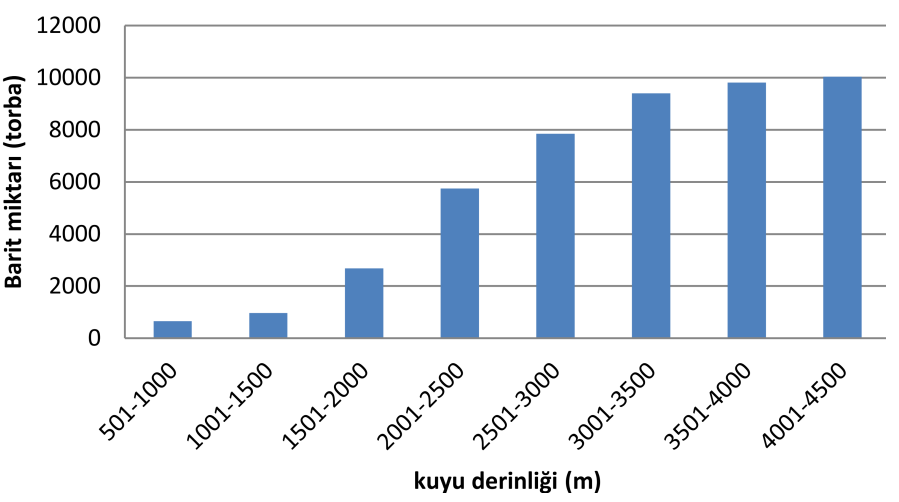

Şekil 6. Kuyularda kullanılan barit miktarı

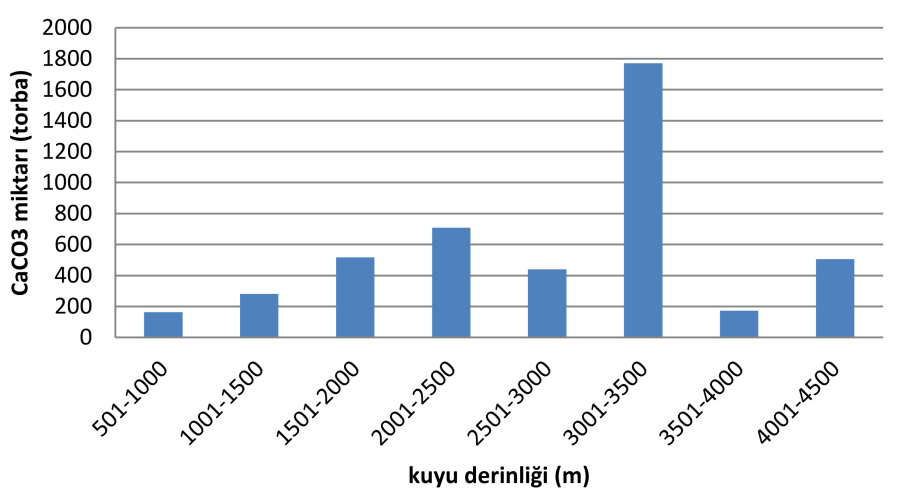

Şekil 7. Kuyularda kullanılan $\mathrm{CaCO}_{3}$ miktarı

\subsection{Tuzlar}

$\mathrm{NaCl}, \mathrm{KCl}$ ve $\mathrm{CaCl}_{2}$ gibi suda çözünebilen tuzlardır. Bunlar, çamur ağırlığını artırmak veya iyonik inhibisyon sağlamak için sondaj ve tamamlama sıvılarının hazırlanmasında kullanılır.

Sodyum Klorür $(\mathrm{NaCl})$, çamur ağırlığını artırmak veya iyonik inhibisyon sağlamak için sondaj ve tamamlama sıvılarının hazırlanmasında kullanılır. Çalışma kapsamında incelenen 470 adet petrol ve doğalgaz sondajında kullanılan $\mathrm{NaCl}$ miktarları Şekil 8'de verilmiştir. NaCl kullanım miktarının 3000 - 3500 m derinliklerde yüksek olduğu görülmektedir.

Potasyum Klorür $(\mathrm{KCl})$ : $\mathrm{KCl}$ çamurunda potasyum inhibisyonunu sağlayan potasyum kaynağı olarak kullanılır. Çalışma kapsamında incelenen 470 adet petrol ve doğalgaz sondajında kullanılan potasyum klorür miktarları Şekil 9'da verilmiştir. KCl kullanım miktarının 2000 - 2500 ve 3500 - 4500 $\mathrm{m}$ derinliklerde yüksek olduğu görülmektedir.

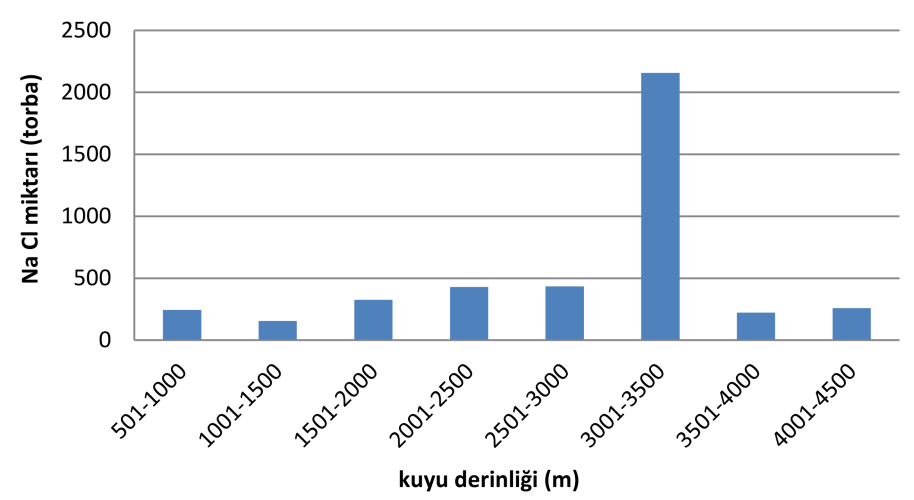

Şekil 8. Kuyularda kullanılan NaCl miktarı

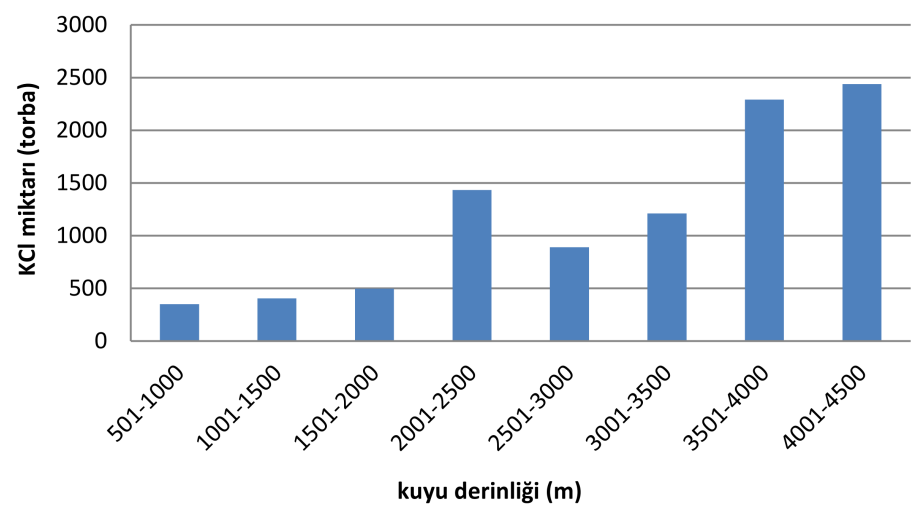

Şekil 9. Kuyularda kullanılan KCl miktarı

\subsection{Polimerler}

Sondaj çamurunun esas olarak sıvı kaybı, viskozite ve jel mukavemeti özelliklerini belirlemek ve kontrol etmek için kullanılan katkı maddeleridir. Kısaca; viskozite yapıcı polimerler, inceltici polimerler ve sıvı kaybı kontrol polimerleri olarak üçe ayrılabilir. Nişasta, Zantam sakızı, CMC (karboksimetil selüloz), PAC (polianyonik selüloz), SAPP (sodyum asit payrofosfat) ve PHPA (kısmen hidrolize poliakrilamitler) vb. gibi polimerler çamur hazırlanması ve istenilen özelliklerin sağlanması ve korunması için sektörde kullanılan belli başlı polimerlerden bazılarıdır.

Therma Thin-İnceltici, polimer esaslı çamurlarda viskozite ve jel artışını önlemek için kullanılır. Çalışma kapsamında incelenen 470 adet petrol ve doğalgaz sondajında kullanilan Therma Thin miktarları Şekil 10'da verilmiştir. Therma Thinİnceltici kullanım miktarlarının kuyu derinliğine göre değişken olmakla birlikte, özellikle 3000 - $3500 \mathrm{~m}$ derinliklerde arttığ görülmektedir. Bu durum, 3000 - 3500 m derinlik seviyelerinde kil baskın birimlerin baskın olduğunu düşündürmektedir. Çünkü, kil baskın seviyelerden sondaj çamurunun kirletilmesi sebebiyle viskozite artışları meydana gelir. Dolayısıyla, çamurun viskozitesinin düşürülmesi nedeniyle incelticilere ihtiyaç duyulur.

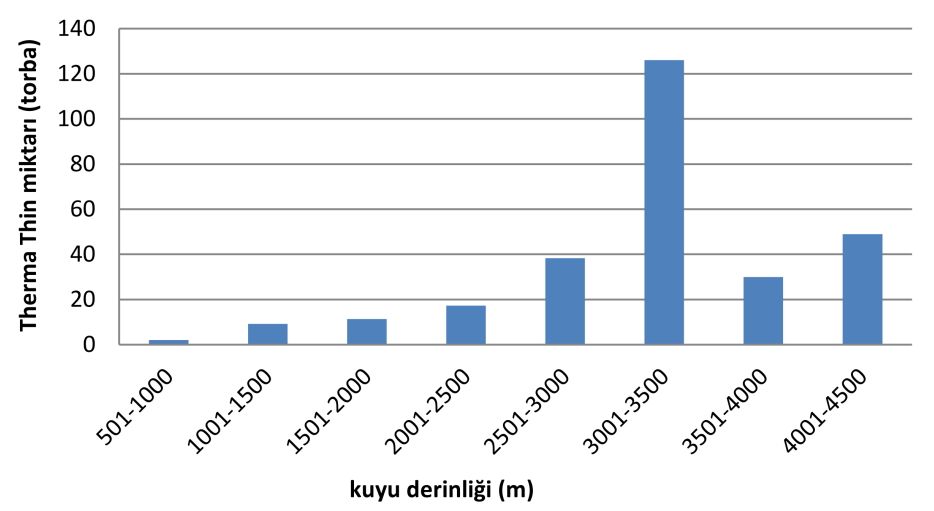

Şekil 10. Kuyularda kullanılan Therma Thin miktarı

Unical (İnceltici), viskoziteyi azaltmak veya topaklanmayı önlemek için kullanılan çamur katkı maddesidir. Çalışma kapsamında incelenen 470 adet petrol ve doğalgaz sondajında kullanılan Unical miktarları Şekil 11'de verilmiştir. Kuyu derinlikleri arttıkça kullanılan inceltici miktarının arttığı görülmektedir.

CMC-LV + Modifiye Nişasta, PAC-LV; CMC-LV (karboksimetil selüloz, düşük viskozite), tatlı su bazlı 
çamurlarda bentonitin yanı sıra su kaybında daha fazla bir azalma sağlamak amacıyla kullanılan bir su kaybı kontrolü maddesidir. Modifiye Nişasta, su bazlı çamurlarda ve tamamlama sıvilarında su kaybını kontrol eder. PAC-LV (Polianyonik selüloz, düşük viskozite), özellikle yüksek konsantrasyonda tuz içeren sistemlerde veya doymuş tuzlu su sistemlerinde sıvı kaybı kontrolünde kullanılır. Çalışma kapsamında incelenen 470 adet petrol ve doğalgaz sondajında kullanılan CMC + Nişaşta miktarları Şekil 12' de, PAC-LV miktarı ise Şekil 13'de verilmiştir. CMC + Nişaşta kullanım miktarlarının 2000 - $4500 \mathrm{~m}$ derinliklerde arttığı (Şekil 12), PAC-LV kullanım miktarlarının ise derinliğe paralel olarak $\operatorname{arttığ1~(Şekil~13)~görülmektedir.~}$
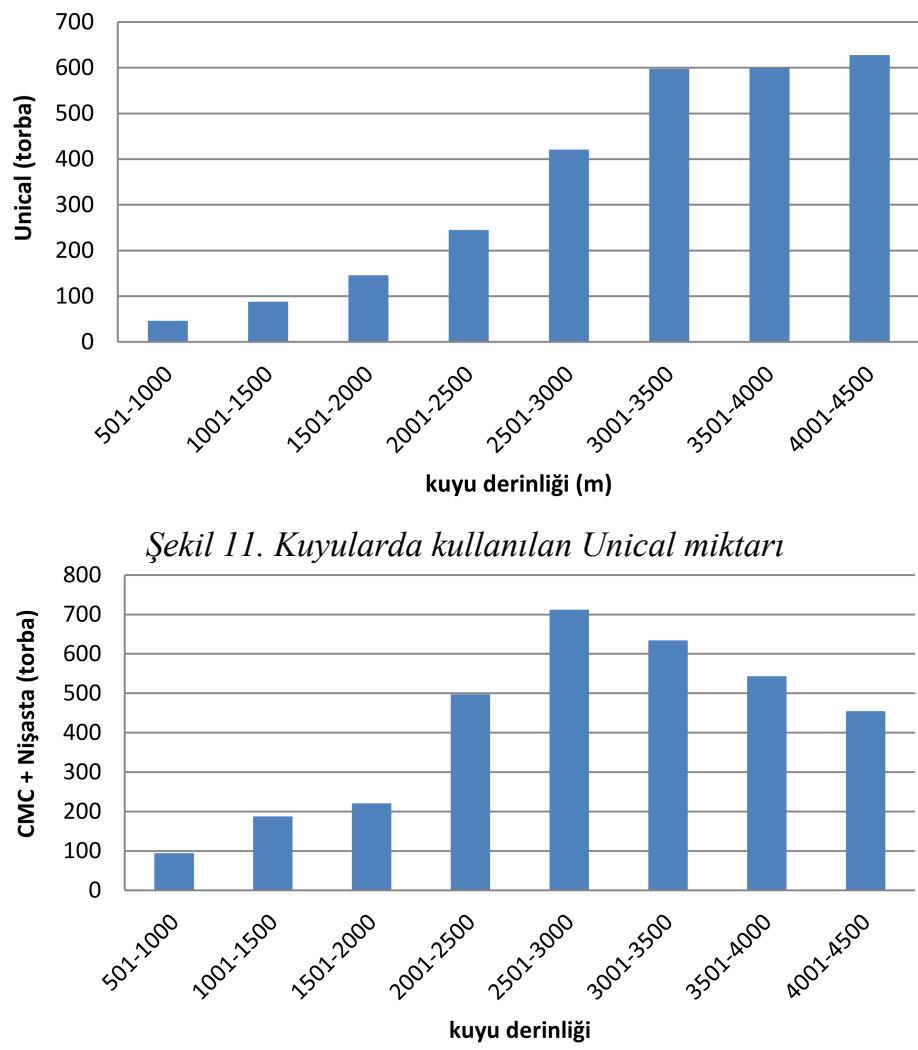

Şekil 12. Kuyularda kullanılan CMC + Nişaşta miktarı

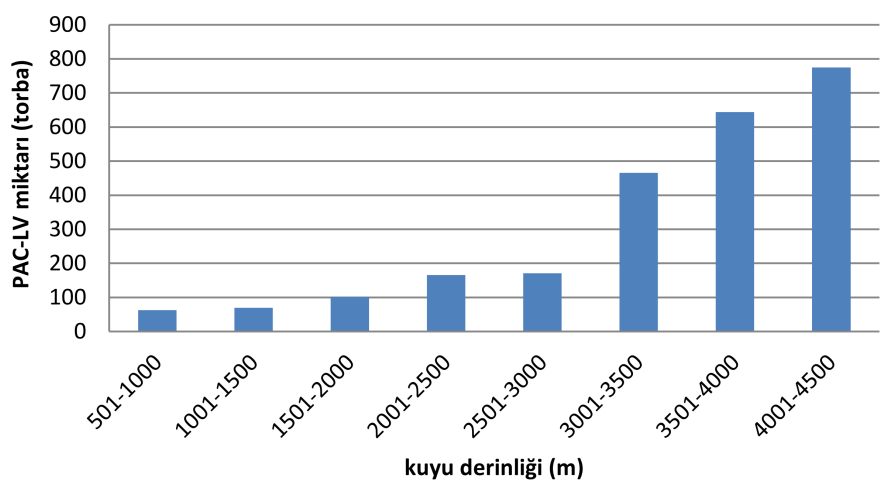

Şekil 13. Kuyularda kullanılan PAC-LV miktarı

XCD polimer, düşük kayma gerinmesi hızlarında viskozite sağlayarak kuyu temizliğine yardımcı olur. Ayrıca, sirkülasyonun kesildiği durumlarda kesintilerin süspansiyonda tutulmasını sağlar. Çalışma kapsamında incelenen 470 adet petrol ve doğalgaz sondajında kullanılan XCD Polimer miktarları Şekil 14'de verilmiștir. XCD Polimer kullanım miktarlarının özellikle 4000 - $4500 \mathrm{~m}$ derinliklerde arttığı görülmektedir.

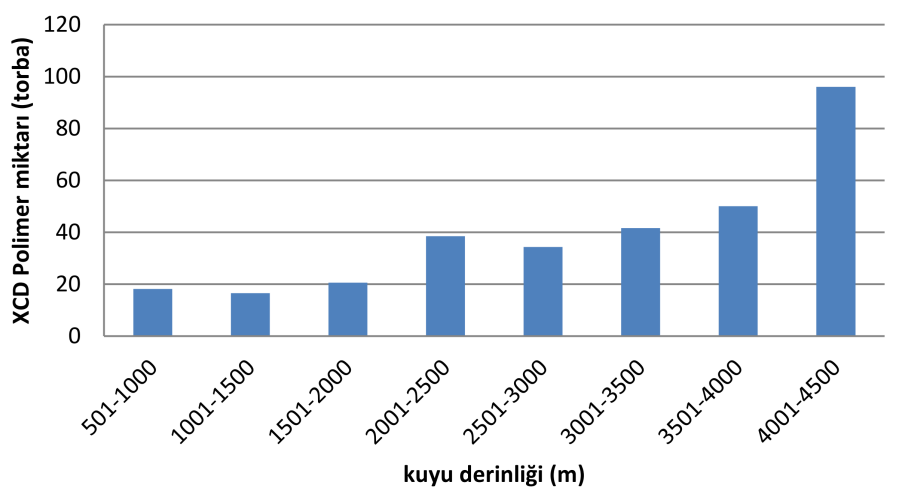

Şekil 14. Kuyularda kullanılan XCD polimer miktarı

PAC-R, tüm su bazlı sondaj sıvılarında, viskozite yapıcı ve su kaybı düşürücü olarak kullanılır. Tuzlu sondaj sıvısında kullanılır. Şeyl hidrasyonu ve dağılmasını önleyerek kuyunun durağanlılığını sağlar. Bakteri bozuşmasından etkilenmez ve geniş $\mathrm{pH}$ aralığında kullanılır. Çalışma kapsamında incelenen 470 adet petrol ve doğalgaz sondajında kullanılan PAC-R miktarları Şekil 15'de verilmiştir. PAC-R kullanım miktarlarının özellikle, 500 - 1000 ve 2000 - 4500 m derinliklerinde arttığ1 görülmektedir.

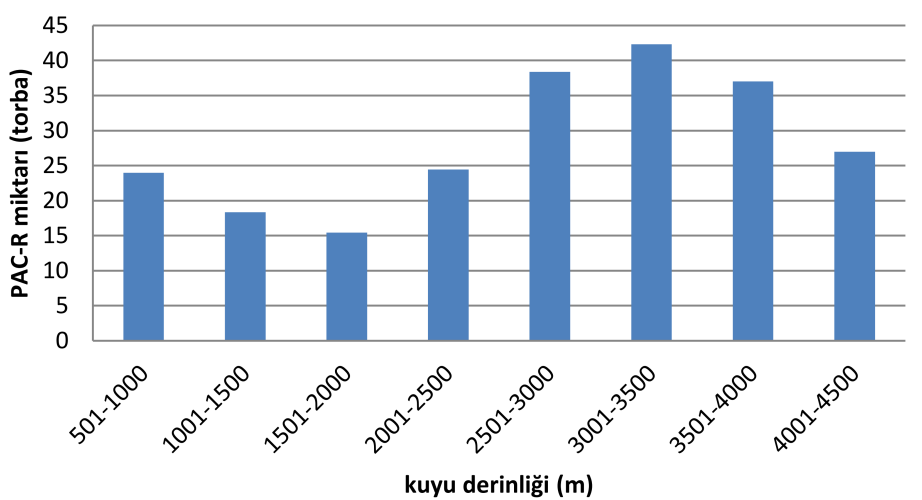

Şekil 15. Kuyularda kullanılan PAC-R miktarı

PHPA, kısmen sulandırılmış poliakrilamid copolimer emülsiyonudur. Su bazlı çamurlarda şeylli ve killi kesintilerin dağılmasını önlemek, kuyu çapında devamlılık sağlamak amacı ile kullanılır. Ayrıca, matkap sarmasını (kafa yapmasını) önler ve dizi üzerinde kayganlık sağlar. Çalışma kapsamında incelenen 470 adet petrol ve doğalgaz sondajında kullanılan PHPA miktarları Şekil 16 'da verilmiştir. Kuyu derinlikleri arttıkça kullanılan PHPA miktarının arttığı görülmektedir.

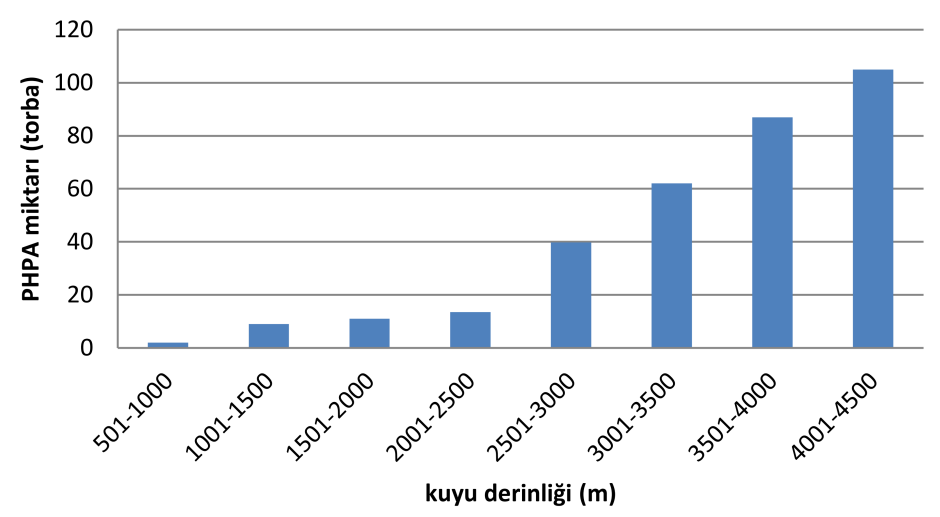

Şekil 16. Kuyularda kullanılan PHPA miktarı 
Flo-vis, ekstra saf XCD polimer türüdür. Açık tamamlama yapılacak kuyularda ve yönlü sondajlarda, çok düşük kayma gerinmesi hızlarında viskozite sağlayarak kuyu temizliğine yardımcı olur. En önemli özelliği, sirkülasyonun kesildiği durumlarda yatay kuyuda kesintilerin süspansiyonda tutulmasını sağlar. Çalışma kapsamında incelenen 470 adet petrol ve doğalgaz sondajında kullanılan Fovis miktarları Şekil 17'de verilmiştir. Kuyu derinlikleri arttıkça kullanılan Flovis miktarının arttığı görülmektedir.

Flo-trol, ekstra saf modifiye nişasta türüdür. Açık tamamlama yapılacak kuyularda su kaybını kontrol etmek amacıyla kullanılır. Çalışma kapsamında incelenen 470 adet petrol ve doğalgaz sondajında kullanılan Flotrol miktarları Şekil 18'de verilmiştir. Kuyu derinlikleri arttıkça kullanılan Flo-trol miktarının arttığı görülmektedir.

Biocide, polimer esaslı çamurlarda bakteri üremesi ve kimyasalların bozulmasını önlemek amacı ile kullanılan sıvı kimyasaldır. Çalışma kapsamında incelenen 470 adet petrol ve doğalgaz sondajında kullanılan Biocide miktarları Şekil 19'da verilmiştir. Biocide kullanım miktarını özellikle 3000 - 4500 m derinliklerde yüksek olduğu görülmektedir.

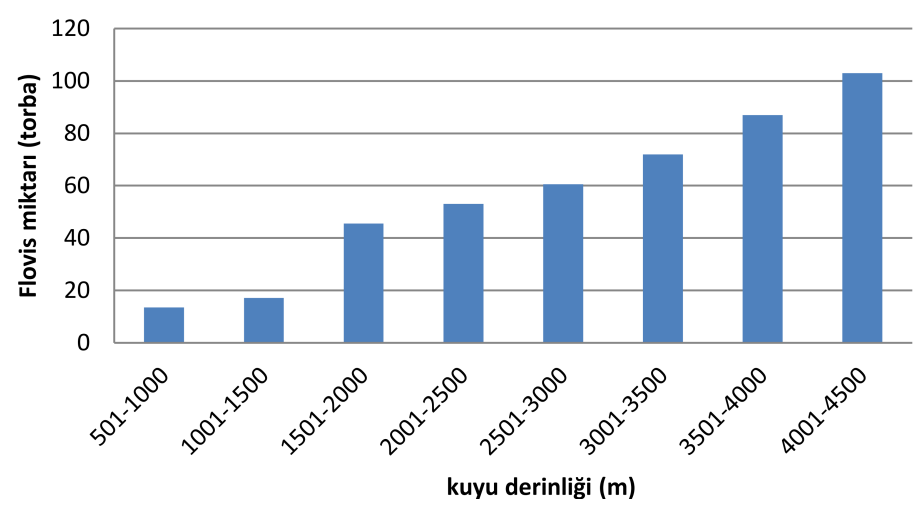

Şekil 17. Kuyularda kullanılan Flovis miktarı

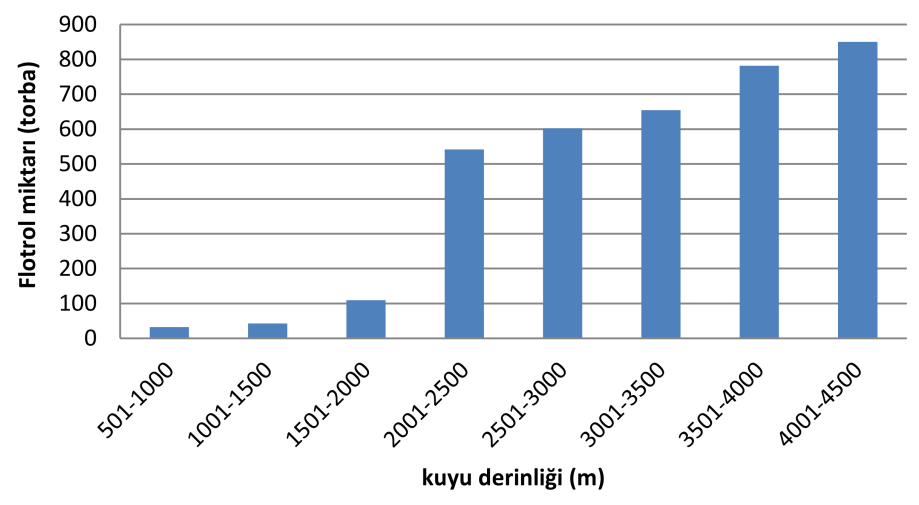

Şekil 18. Kuyularda kullanılan Flotrol miktarı

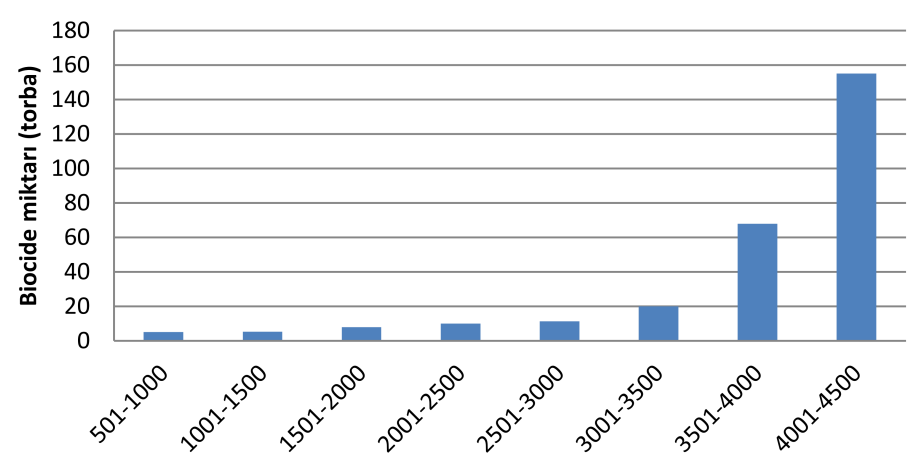

Sekil 19. Kuyularda kullanılan Biocide miktarı

\subsection{Kaçak Önleyici Maddeler}

Geçirgen ve çatlaklı yapıların sondajı sırasında karşılaşılabilecek çamur kaçaklarının önlenmesi için kullanılan malzemelerdir. Kullanım amacı çamur kaçaklı yapıları tıkayarak sirkülasyonun kazanılması ve çamur kaçaklarının azalmasını sağlamaktır. Fiber yapılı (saman vs.), pullu (mika vs.) ve granüllü (fındık kabuğu vb.) malzemeler olarak üçe ayırabiliriz. Farklı kaçak hızları doğrultusunda farklı konsantrasyonlarda çamura ilavesi ile kaçaklı yapıları tıkamak için kullanılabilir.

Saman, geçirgen ve çatlaklı yapıların sondajı sırasında karşılaşılabilecek çamur kaçaklarının önlenmesi için kullanılan bir maddedir. Çalışma kapsamında incelenen 470 adet petrol ve doğalgaz sondajında kullanılan saman miktarları Şekil 20'de verilmiştir. Kuyularda büyük hacimde saman kullanımı, 2500 $3000 \mathrm{~m}$ ve 4000 - $4500 \mathrm{~m}$ derinliklerde gerçekleşmiştir. Dolayısıyla, Türkiye'deki petrol ve doğalgaz sondajlarında en büyük hacimli çamur kaçaklarının 2500 - $3000 \mathrm{~m}$ ve 4000 - 4500 $\mathrm{m}$ derinliklerde olduğu anlaşılmaktadır.

Mika, kaçak tıkamada kullanılan asitte çözünmeyen bir mineraldir. Çalışma kapsamında incelenen 470 adet petrol ve doğalgaz sondajında kullanılan mika miktarları Şekil 21'de verilmiştir. Kuyularda, mika kullanımının kuyu derinliklerine göre oldukça değişken olduğu görülmektedir.

Findık kabuğu, farklı konsantrasyonlarda çamura ilave edilerek kaçaklı yapıları tıkamak için kullanılabilir. Çalışma kapsamında incelenen 470 adet petrol ve doğalgaz sondajında kullanılan findık kabuğu miktarları Şekil 22'de verilmiștir. Kuyu derinlikleri arttıkça kullanılan findık kabuğu miktarının arttı̆̆ görülmektedir.

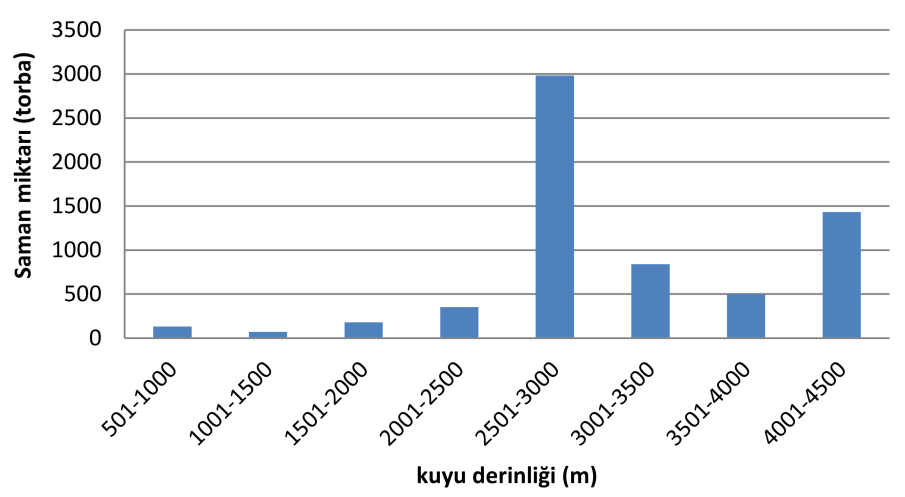

Şekil 20. Kuyularda kullanılan saman miktarı

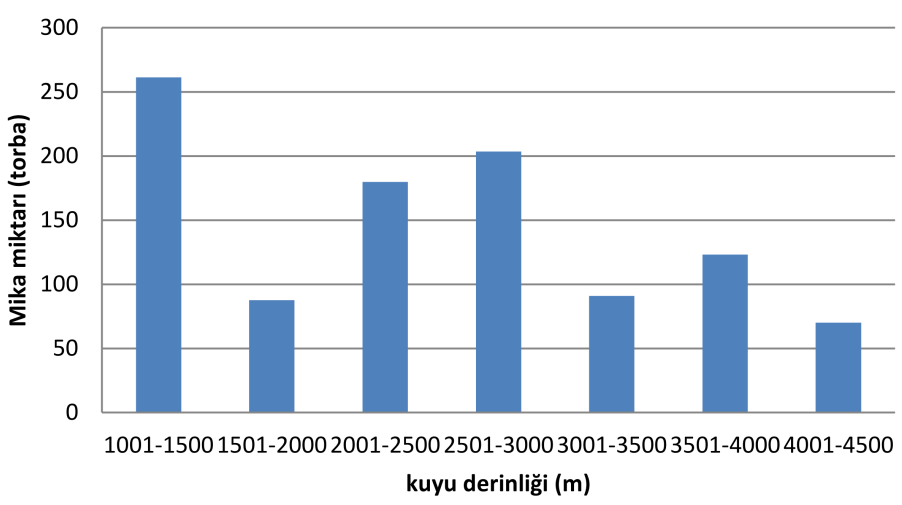

Şekil 21. Kuyularda kullanılan mika miktarı 


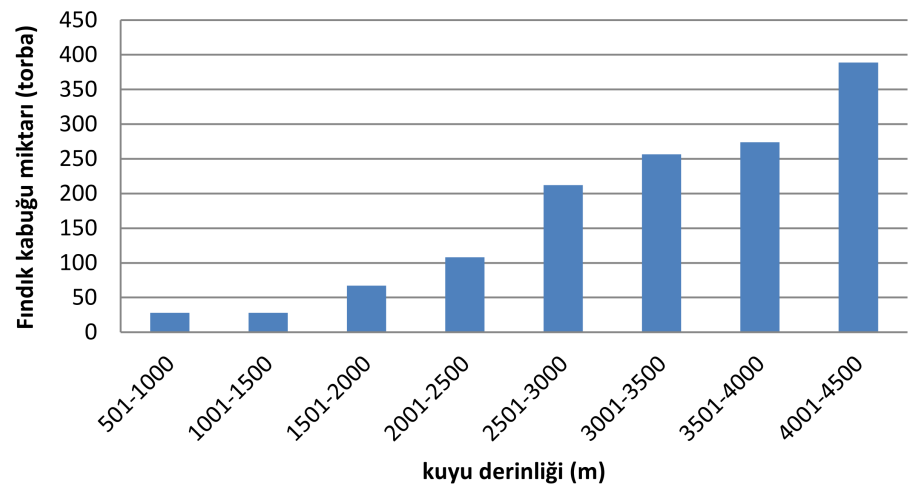

Şekil 22. Kuyularda kullanılan findık kabuğu miktarı

\subsection{Diğer Katkı Maddeleri}

Kostik Soda $(\mathrm{NaOH})$, sondaj çamurunun pH'ını ayarlamada kullanılmaktadır. Ayrıca, çamur pH'ı düzenleme ve kimyasal kirliliklerin ıslahı için sodyum bikarbonat, soda külü ve kireç gibi malzemeler de kullanılmaktadır. Çalışma kapsamında incelenen 470 adet petrol ve doğalgaz sondajında kullanılan kostik miktarları Şekil 23'de verilmiştir. Kuyu derinlikleri arttıkça kullanılan kostik soda miktarının arttığı görülmektedir.

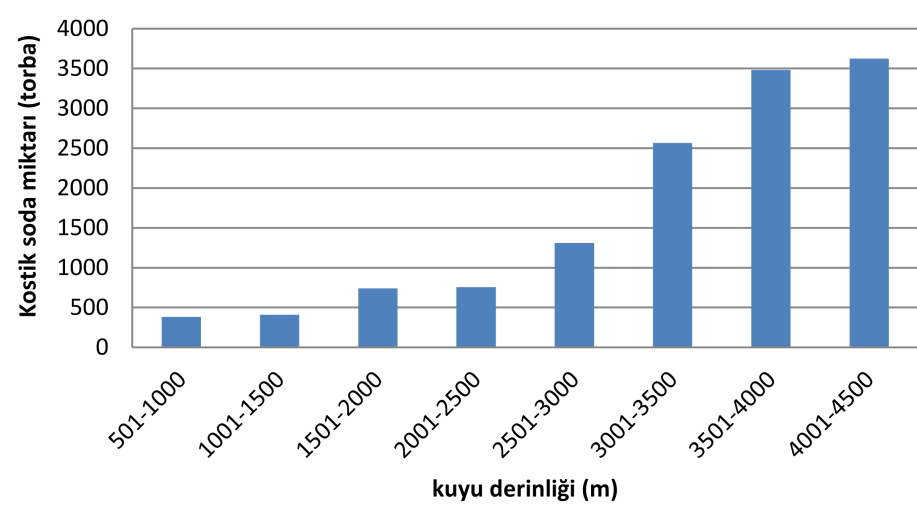

Şekil 23. Kuyularda kullanılan kostik soda miktarı

Ham petrol ve motorin, sondaj operasyonları sirasında petrol ve sentetik bazlı çamurlar vb. gibi organik bazlı çamurlar kullanılabilir. Petrol bazlı çamurlar dış fazı petrol, mazot veya mineral yağdan; iç faz ise sodyum/kalsiyum klorür içeren sudan oluşan petrol-su emülsiyonlarıdır. Petrol bazlı çamurlar aktif formasyonlarda en fazla korumayı sağlayan çamur tipidir. Çevre koşulları düşünülerek, petrol bazlı çamurların yerine geçebilecek sentetik bazlı çamur sistemleri de mevcuttur. Çalışma kapsamında incelenen 470 adet petrol ve doğalgaz sondajında kullanılan ham petrol miktarları Şekil 24'te, motorin miktarları da Şekil 25 'te verilmiştir. Ham petrol kullanım miktarlarının oldukça değişik olmakla birlikte 3000 - 3500 m derinliklerde arttığı (Şekil 24), motorin kullanım miktarlarının ise derinliğe paralel olarak arttığı (Şekil 25) görülmektedir.

Lube-167, takım sıkışması riskini azaltmak, takım dizisinde oluşacak torkların önüne geçmek ve yüzeysel sıkışma olasılığını en aza indirmek için kuyu içinde yağlama amacı ile kullanılır. Kuyu içindeki dizi ve formasyon arasında kayganlık sağlayan bir film oluşturur. Çalışma kapsamında incelenen 470 adet petrol ve doğalgaz sondajında kullanılan Lube-167 miktarları Şekil 27'de verilmiştir. Yüksek Lube-167 kullanım miktarları, 1000 - 1500 $\mathrm{m}$ ve 3000 - $4000 \mathrm{~m}$ derinliklerde gerçekleşmiştir. Dolayısıyla, Türkiye'deki petrol ve doğalgaz sondajlarında takım sıkışması riski ve tork almanın özellikle 3000 - $4000 \mathrm{~m}$ ve $1000-1500 \mathrm{~m}$ derinliklerde olduğu anlaşılmaktadır.

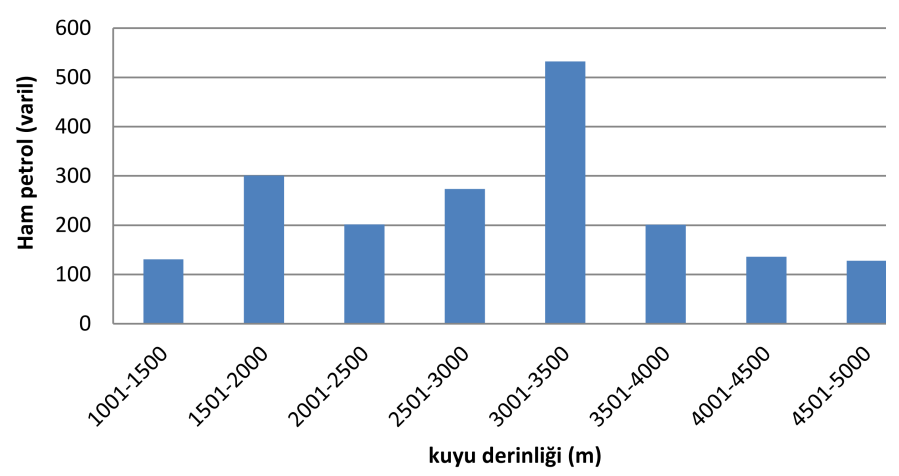

Şekil 24. Kuyularda kullanılan ham petrol miktarı

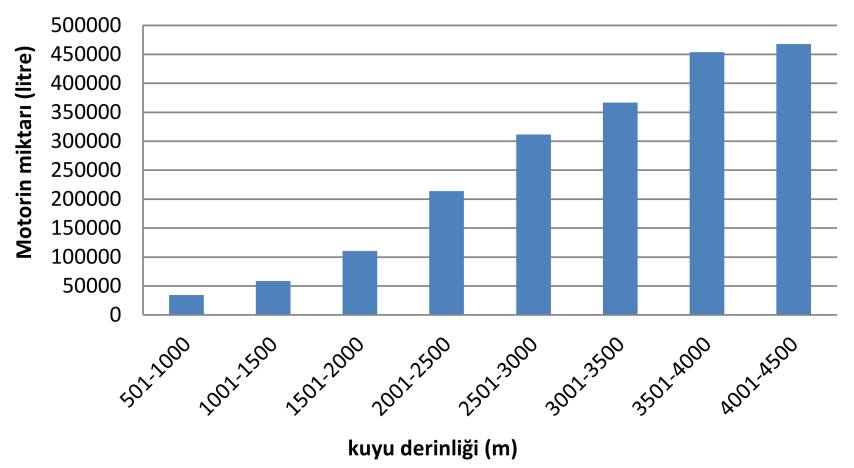

Şekil 25. Kuyularda kullanılan motorin miktarl

Alüminyum Sterat, mazot ile karıştırılarak özellikle bentonit bazlı çamurlardaki köpüğü kırmak için kullanılan bir kimyasaldır. Bir varil mazota $25 \mathrm{~kg}$ Alüminyum Steart eklenir ve karıştırılarak sistem çamuruna tedrici olarak verilir. Çalışma kapsamında incelenen 470 adet petrol ve doğalgaz sondajında kullanılan Alüminyum Sterat miktarları Şekil 26'da verilmiştir. Alüminyum Sterat kullanım miktarının özellikle 4000 - 4500 m derinliklerde yüksek olduğu görülmektedir.

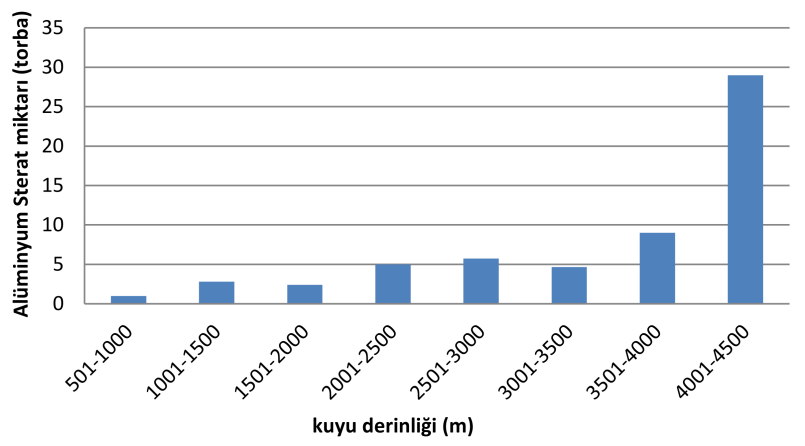

Şekil 26. Kuyularda kullanılan Alüminyum Sterat miktarları

Kireç, çamur pH'ı düzenleme ve kimyasal kirliliklerin ıslahı için kireç kullanılmaktadır. Çalışma kapsamında incelenen 470 adet petrol ve doğalgaz sondajında kullanılan kireç miktarları Şekil 28'de verilmiştir. Kuyu derinlikleri arttıkça kullanılan kireç miktarının arttığı görülmektedir.

Potasyum hidroksit (KOH), sondaj sıvılarının pH'ını ayarlamak için kullanılır. Aynı zamanda, sisteme gerekli olan potasyum iyonunu da sağlar. Çalışma kapsamında incelenen 470 adet petrol ve doğalgaz sondajında kullanılan $\mathrm{KOH}$ miktarları Şekil 29'da verilmiştir. Şekilde, kuyu derinlikleri arttıkça kullanılan KOH miktarının arttığı görülmektedir. 


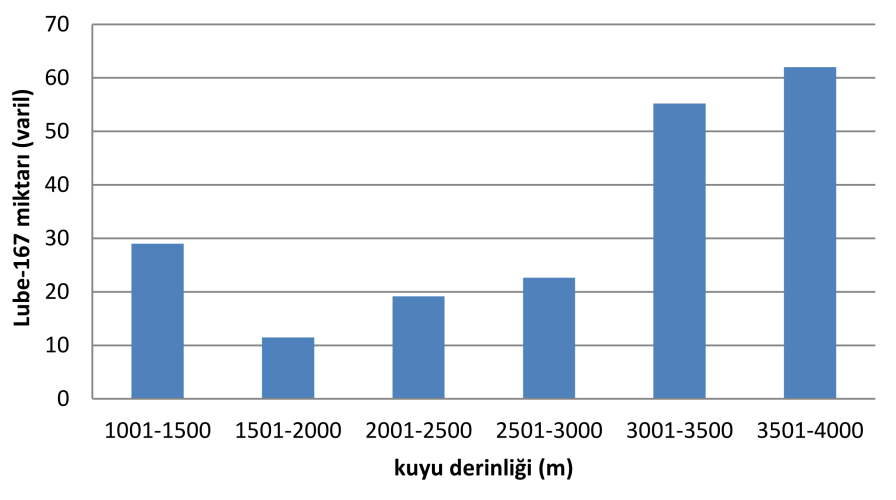

Şekil 27. Kuyularda kullanılan Lube-167 miktarı

Defoamer, polimer çamurlarında karşılaşılan köpük sorununa karşı kullanılır. Çamur yapımı sırasında, tank üzerinde oluşacak köpük $1 / 4$ bidon köpük kırıcı serpilmesi yolu ile önlenir. Çalışma kapsamında incelenen 470 adet petrol ve doğalgaz sondajında kullanılan Defoamer miktarları Şekil 30'da verilmiştir. Kuyularda, Defoamer kullanımının kuyu derinliklerine göre oldukça değişken olduğu görülmektedir.

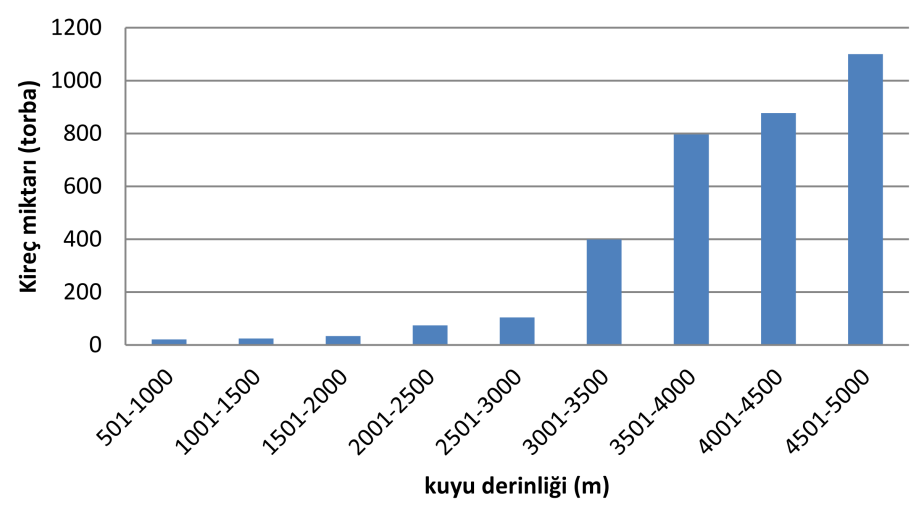

Şekil 28. Kuyularda kullanılan kireç miktarı

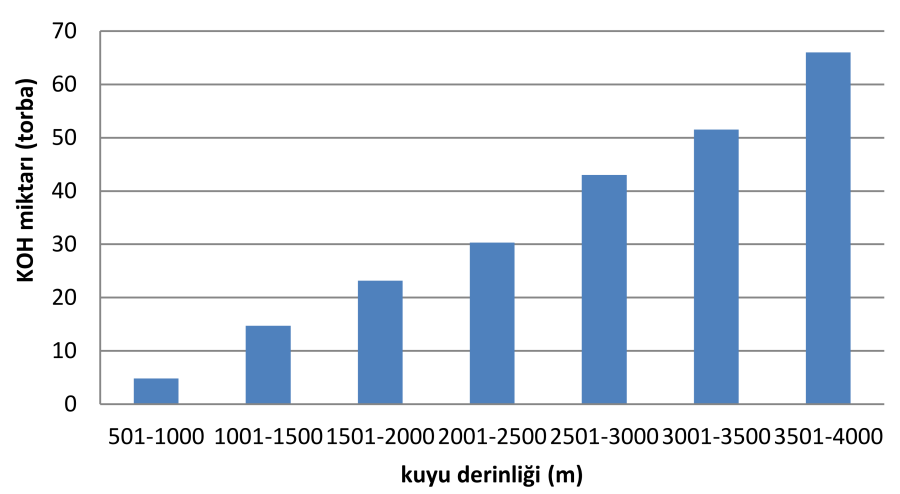

Sekil 29. Kuyularda kullanilan KOH miktarı

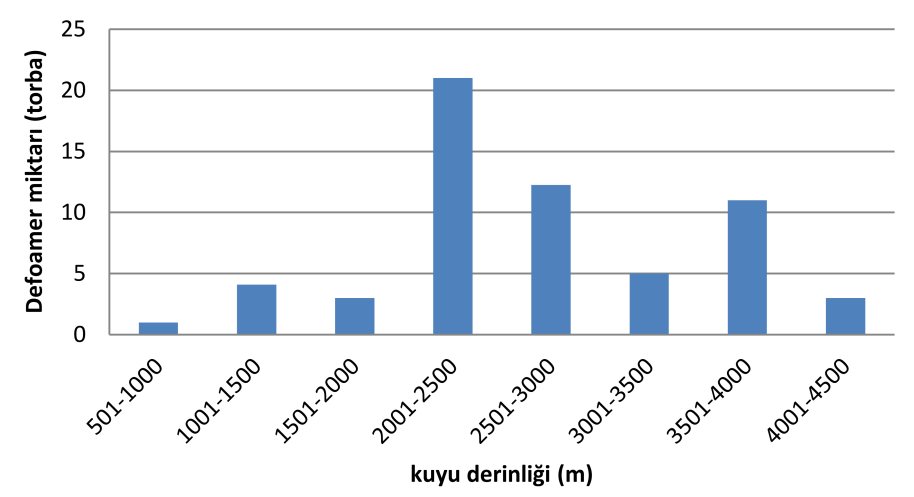

Glikol, sıvı kaybı kontrolünde kullanılan, kuyu stabilitesinin korunmasını ve dizi üzerinde kayganlık sağlayan, kesintilerin dağılmasını önleyen, yüksek sıcaklıklara dayanıklı alkol bazlı sıvıdır. Hacimce \% 3 oranında kullanılır. Çalışma kapsamında incelenen 470 adet petrol ve doğalgaz sondajında kullanılan glikol miktarları Şekil 31'de verilmiştir. Kuyu derinlikleri arttıkça kullanılan Glikol miktarının arttığı görülmektedir.

Sitrik asit, bir hidrojen $\left(\mathrm{H}^{+}\right)$iyonu kaynağı olarak sondaj sıvısının pH'ını düşürmek için kullanılır. Sitrik asit aktif killerin etrafında hidrojen iyonu katmanı oluşturarak killerin zeta potansiyelini (tanecikler arasındaki itme ve çekme değeri) düşürerek su emme kabiliyetini zayıflatır. $\mathrm{Bu}$ da killerin parçalanarak sondaj akışkanında şişmesini azaltır. Çalışma kapsamında incelenen 470 adet petrol ve doğalgaz sondajında kullanılan sitrik asit miktarları Şekil 32'de verilmiştir. Kuyularda, sitrik asit kullanımının kuyu derinliklerine göre oldukça değişken olduğu görülmektedir.

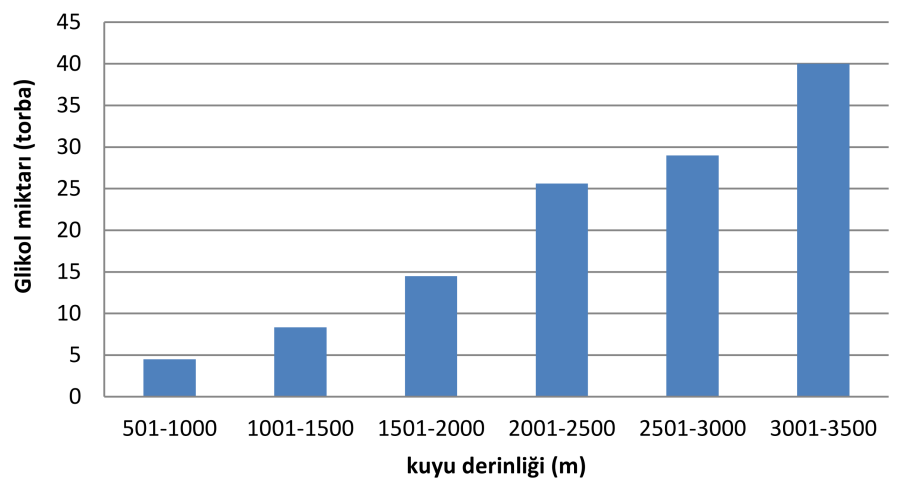

Şekil 31. Kuyularda kullanılan glikol miktarı

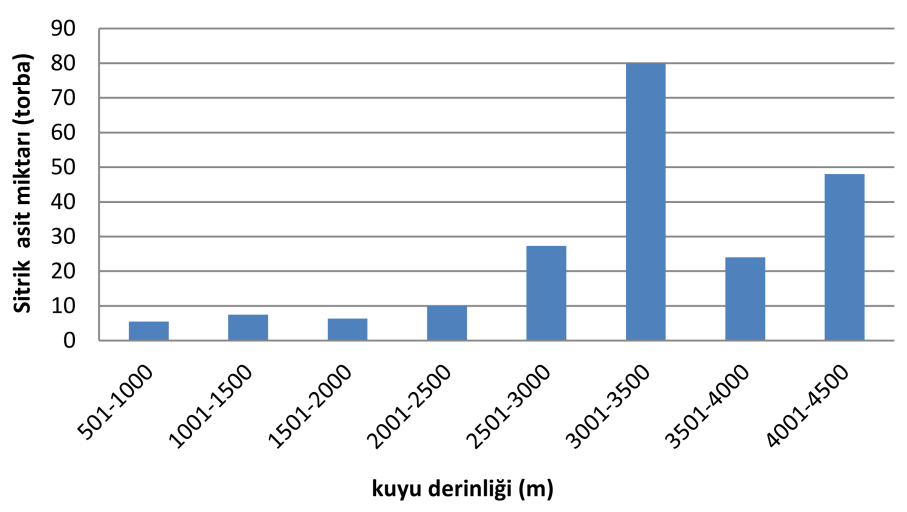

Şekil 32. Kuyularda kullanılan sitrik asit miktarı

Ironide Sponge, $\mathrm{H}_{2} \mathrm{~S}$ kirlenmelerinde kullanılan, sülfür iyonu ile reaksiyona giren bir kimyasaldır. Çalışma kapsamında incelenen 470 adet petrol ve doğalgaz sondajında kullanılan Iron-Sp miktarları Şekil 33'de verilmiştir. Kuyu derinlikleri arttıkça kullanılan Iron-Sp miktarının arttığı görülmektedir. 


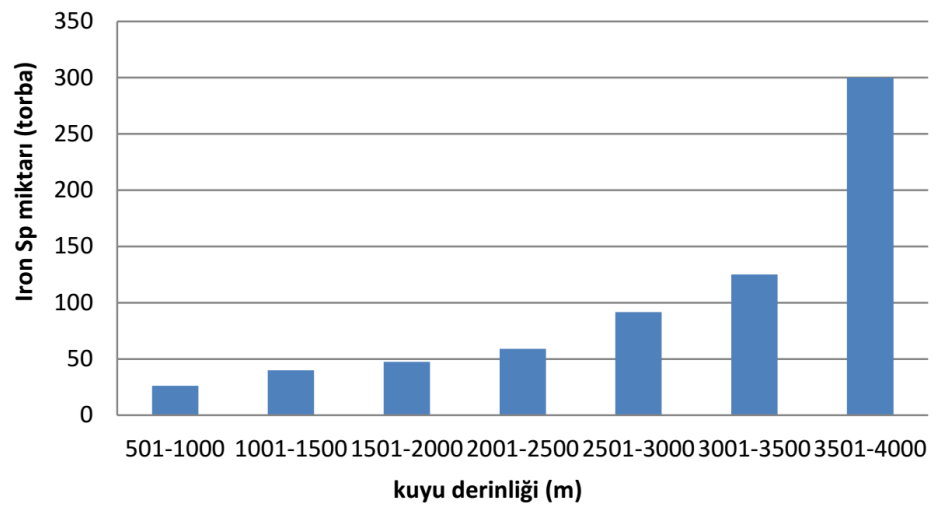

Şekil 33. Kuyularda kullanılan Iron Sp miktarı

\section{Sonuçlar}

Türkiye kara alanlarında delinmiş olan verisi değerlendirilen 470 adet petrol ve doğalgaz sondaj kuyusunda, sı ğ derinliklerde $(0-50 \mathrm{~m})$ spud çamuru, daha sonraki derinliklerde de lignosülfanat çamuru kullanıldığı görülmüştür. Çalışma sonuçları şu şekildedir;

- Kuyu derinlikleri arttıkça kullanılan bentonit miktarının arttığı görülmektedir. Bunun sebebi, kuyu derinlikleri arttıkça kuyu içi hidrostatik basınçların dengelenmesi için sondaj çamuru yoğunluğunun dengede tutulma zorunluluğunun ortaya çıkmasıdır.

- Kuyu derinlikleri arttıkça kullanılan barit miktarının arttığı görülmektedir. Bunun nedeni, kuyu derinlikleri arttıkça kuyu içi hidrostatik basınçların dengelenmesi için sondaj çamuru yoğunluğunun arttırılma zorunluluğunun ortaya çıkmasıdır.

- Kuyu derinlikleri arttıkça kullanılan PHPA, kostik soda, $\mathrm{KOH}$, inceltici, Flo-vis, Flo-trol, findık kabuğu, kireç, glikol ve Iron-Sp miktarlarının arttığı görülmektedir.

- Kuyularda büyük hacimde saman kullanımı, 2500 - 3000 $\mathrm{m}$ ve $4000-4500 \mathrm{~m}$ derinliklerde gerçekleşmiştir. Dolayısıyla, Türkiye'deki petrol ve doğalgaz sondajlarında en büyük hacimli çamur kaçaklarının 2500 - 3000 m ve 4000 - 4500 m derinliklerde olduğu anlaşılmaktadır.

- Ham petrol kullanım miktarlarının oldukça değişik olmakla birlikte 3000 - $3500 \mathrm{~m}$ derinliklerde arttığı, Motorin kullanım miktarlarının ise derinliğe paralel olarak arttı̆̆ görülmektedir.

- Yüksek Lube-167 kullanım miktarları, 1000 - $1500 \mathrm{~m}$ ve 3000 - $4000 \mathrm{~m}$ derinliklerde gerçekleşmiş̧ir. Dolayısıyla, Türkiye'deki petrol ve doğalgaz sondajlarında takım sıkışması riski ve tork almanın özellikle $3000-4000 \mathrm{~m}$ ve $1000-1500 \mathrm{~m}$ derinliklerde olduğu anlaşılmaktadır.

\section{Kaynakça}

Acar, İ., Doğan, E., Urhan, F., Ak, A.Ö. (2020). İki farklı polimerin sondaj çamuru özellikleri üzerine etkileri. Avrupa Bilim ve Teknoloji Dergisi, 20, 479-484, doi: 10.31590/ejosat.765132

Balkaya, T.A. (2019). Sondaj El Kitabı. Petrol Mühendisleri Odası Yayını. $75 \mathrm{~s}$.

Büyükgöz, H. (2004). Petrol Sondajlarında Çamur. Çukurova Üniversitesi, Yüksek Lisans Tezi, $73 \mathrm{~s}$.
Ettehadi, A. (2021). An experimental study on structural and thermal stability of water-based drilling fluids. Avrupa Bilim ve Teknoloji Dergisi, 23, 70-80, doi: 10.31590/ejosat. 843568

Güllü, A., Yaşar, E. ve Özdemir, A. (2021). Türkiye'deki petrol ve doğalgaz kuyularının optimizasyonu. IMAEC 2. Uluslararası Matematik, Mimarlı ve Mühendislik Kongresi, 22-32

Ozdemir, A., Güllü, A., Yaşar, E. and Palabiyik, Y. (2021a). Drilling engineering assessment and cost analysis of oil and gas wells drilled in onshore of Turkey. International Journal of Earth Sciences Knowledge and Applications, $3(3), 235-243$

Ozdemir, A., Yaşar, E., Palabiyik, Y. and Güllü, A. (2021b). Relationship between rates of penetration and costs of tricone rock bits: Cases from Southeastern Anatolia and Thrace basins (Turkey). International Journal of Earth Sciences Knowledge and Applications (baskıda)

Ozdemir, A., Palabiyik, Y., Yaşar, E., and Güllü, A. (2021c). A new approach to estimating drilling time, rate of penetration, and drillability of formations in oil and gas exploration and production basins of Turkey. Geomechanics and Geophysics for Geo-Energy and GeoResources (baskida)

Tuğan, M.F., Yardımcı, O., Aydın, H., Gözel, M.E., Kor, K., Merey, Ş., Özgür, E., Öztürk, M.T., Yüce., U. (2020). 21. Yüzyılda Petrol ve Doğal Gaz Mühendisliği, Gazi Kitabevi, $345 \mathrm{~s}$. 